Cite this: Med. Chem. Commun., 2013, 4, 1562

Received 24th July 2013 Accepted 20th September 2013

DOI: $10.1039 / \mathrm{c} 3 \mathrm{md} 00214 \mathrm{~d}$

www.rsc.org/medchemcomm

\title{
Preparation of phenylethylbenzamide derivatives as modulators of DNMT3 activity
}

\author{
Anzhelika Kabro, ${ }^{a}$ Hugo Lachance, ${ }^{\text {ab }}$ Iris Marcoux-Archambault, ${ }^{a}$ Valérie Perrier, ${ }^{a}$ \\ Vicky Doré, a Christina Gros, ${ }^{c}$ Véronique Masson, ${ }^{c}$ Jean-Marc Gregoire, ${ }^{c}$ \\ Frédéric Ausseil,' ${ }^{c}$ David Cheishvili, ${ }^{d}$ Nathalie Bibens Laulan, ${ }^{e}$ Yves St-Pierre, $^{\text {be }}$ \\ Moshe Szyf, ${ }^{d}$ Paola B. Arimondo ${ }^{\star c}$ and Alexandre Gagnon*ab
}

\begin{abstract}
DNA-methyltransferases (DNMTs) are a class of epigenetic enzymes that catalyze the transfer of a methyl moiety from the methyl donor S-adenosyl-L-methionine onto the C5 position of cytosine in DNA. This process is dysregulated in cancers and leads to the hypermethylation and silencing of tumor suppressor genes. The development of potent and selective inhibitors of DNMTs is of utmost importance for the discovery of new therapies for the treatment of cancer. We report herein the synthesis and DNMT inhibitory activity of 29 analogues derived from NSC 319745. The effect of selected compounds on the methylation level in the MDA-MB-231 human breast cancer cell line was evaluated using a luminometric methylation assay. Molecular docking studies have been conducted to propose a binding mode for this series.
\end{abstract}

\section{Introduction}

Epigenetics is defined as the changes that occur on chromosomes without alteration of the DNA sequence and that lead to a stable phenotype. ${ }^{1}$ Epigenetic information is regulated by chromatin modifications, which involve histones and DNA. ${ }^{2}$ DNA methylation is a stable epigenetic modification leading to the installation of a methyl group at the $\mathrm{C} 5$ position of cytosine. ${ }^{3}$ This reaction is catalyzed by DNA methyltransferase (DNMT) enzymes, which use $S$-adenosyl-t-methionine (SAM) as methyl donor. The products of the reaction are 5-methylcytosine in DNA and $S$-adenosyl-L-homocysteine (SAH). ${ }^{4}$ Five DNMTs have been identified: DNMT1, DNMT2, DNMT3A, DNMT3B, and DNMT3L. However, only DNMT1 and DNMT3A/B are catalytically active on DNA. In fact, DNMT2 has a very weak DNA methylation activity and rather performs the methylation of

${ }^{a}$ Université du Québec à Montréal, Département de chimie, Case Postale 8888, Succursale Centre-Ville, Montréal, Québec, H3C 3P8, Canada. E-mail: gagnon. alexandre@uqam.ca; Fax: +1-514-987-4054; Tel: +1-514-987-3000 ext. 6856

${ }^{b}$ Pharmaqam, Département de chimie, Case Postale 8888, Succursale Centre-Ville, Montréal, Québec, H3C 3P8, Canada. E-mail: gagnon.alexandre@uqam.ca; Fax: +1514-987-4054; Tel: +1-514-987-3000 ext. 6856

'USR CNRS-Pierre Fabre no 3388-ETaC Epigenetic Targeting of Cancer, CRDPF 3 avenue Hubert Curien, 31035 Toulouse Cedex 01, France. E-mail: paola.arimondo@ etac.cnrs.fr; Fax: +33 5345034 92; Tel: +33 534506492

${ }^{d}$ Department of Pharmacology and Therapeutics, McGill University, 3655 Sir William Osler Promenade, Montréal, Québec, H3G 1Y6, Canada. E-mail: moshe.szyf@mcgill. ca; Fax: +1-514-398-6690; Tel: +1-514-398-7107

${ }^{e}$ Centre INRS-Institut Armand-Frappier, 531 Boulevard des Prairies, Laval, Québec, H7V 1B7, Canada. E-mail: yves.st-pierre@iaf.inrs.ca; Fax: +1-450-686-5501; Tel: +1450-686-5354
tRNA $^{\text {Asp }}{ }^{5}$ DNMT3L is catalytically inactive since it lacks the necessary catalytic domain. However, DNMT3L has been found to associate with DNMT3A/B to modulate its activity. DNMT3A/ $\mathrm{B}$ are involved in de novo methylation of DNA, initiating methylation on a strand of DNA that is complementary to either the unmethylated or methylated DNA template. Thus, DNMT3A/B can generate new DNA methylation sites irrespective of the pattern of methylation of template DNA. ${ }^{6}$ DNMT1 is implicated in the maintenance of methylation patterns during cell division and methylates hemimethylated DNA. Therefore, DNMT1 copies the pattern of methylation from the parental strand to the nascent strand. ${ }^{7}$

In cancer cells, abnormal DNA methylation of the genome is observed with both hypomethylation and hypermethylation of critical genes $^{8}$ as well as global reduction in the level of DNA methylation across the genome ${ }^{9}$ and hypermethylation of $\mathrm{CpG}$ islands in the promoter regions of some specific genes such as tumor suppressor genes. This process leads to silencing of those genes due to poor recognition by transcription factors and recruitment of proteins involved in the chromatin remodeling such as the methyl-binding proteins (MBD). ${ }^{10}$ Contrary to sequence aberrations, DNA methylation is a reversible process. ${ }^{11}$ More importantly, DNA methyltransferases are aberrantly deregulated and were proposed two decades ago as novel anticancer targets. ${ }^{\mathbf{1 2}}$ In fact, experiments suggest that inhibition of DNMTs can lead to demethylation and reactivation of epigenetically silenced tumor suppressor genes. ${ }^{13}$ Moreover the emergence of the field of "behavioral epigenetics" points to the possibility that DNA methylation inhibitors might be of value in treating mental health diseases and psychopathology 
disorders. ${ }^{14}$ Since neurons are postmitotic, DNA methylation inhibitors that are not incorporated into DNA will be needed. Consequently, DNMT1 and DNMT3 ${ }^{15}$ constitute highly valuable targets for drug development. ${ }^{16,17}$

The discovery of potent and selective inhibitors of DNMTs is of utmost importance for the development of novel therapies for the treatment of cancer $^{\mathbf{1 8}}$ and for the generation of toolcompounds for studying the involvement of DNMTs in the development of various diseases. ${ }^{19}$ Two inhibitors of DNMTs have been approved by the FDA for the treatment of myelodysplastic syndrome (MDS) and acute myeloid leukemia (AML): 5-azacytidine (Vidaza) and 5-aza-2'-deoxycytidine (Dacogen). ${ }^{20}$ After being phosphorylated, these suicide substrates are incorporated into the DNA where they trap the DNMT by forming a covalent adduct thus preventing the regeneration of the catalytic cysteine. ${ }^{21}$ This process leads to the inactivation of the DNMT, which allows the demethylation of tumor suppressor genes and their reactivation. However, these drugs are poorly bioavailable, non-selective and are incorporated everywhere in the genome. As a consequence, there is an urgent need for new potent and selective inhibitors of DNMTs that possess good pharmacokinetic profiles and that show minimal toxicity.

DNMT inhibitors that do not rely on incorporation into DNA might offer a larger therapeutic window and a viable alternative to current treatments. A number of non-nucleoside inhibitors of DNMTs have been reported in the literature. ${ }^{22}$ Natural products such as EGCG $^{23}$ curcumin ${ }^{24}$ caffeic acid, ${ }^{25}$ parthenolide, nanaomycin A, mahanine, and genistein, ${ }^{\mathbf{2 6}}$ and drugs that are approved for other indications such as hydralazine, ${ }^{27}$ procaine, ${ }^{28}$ and procainamide ${ }^{29}$ have also been shown to inhibit DNMTs. $^{30}$

The discovery of small-molecule non-nucleoside inhibitors of DNMTs has been accomplished using virtual ${ }^{31}$ or medium throughput screening ${ }^{32}$ on various compound collections. This process has led to the identification of a limited number of compounds that inhibit DNMTs in the micromolar or submicromolar range, such as the NSC series (Fig. 1). Two other potent inhibitors of DNMTs, RG108 ${ }^{33}$ and SGI $1027,{ }^{34}$ are commonly used as reference compounds in screening assays.

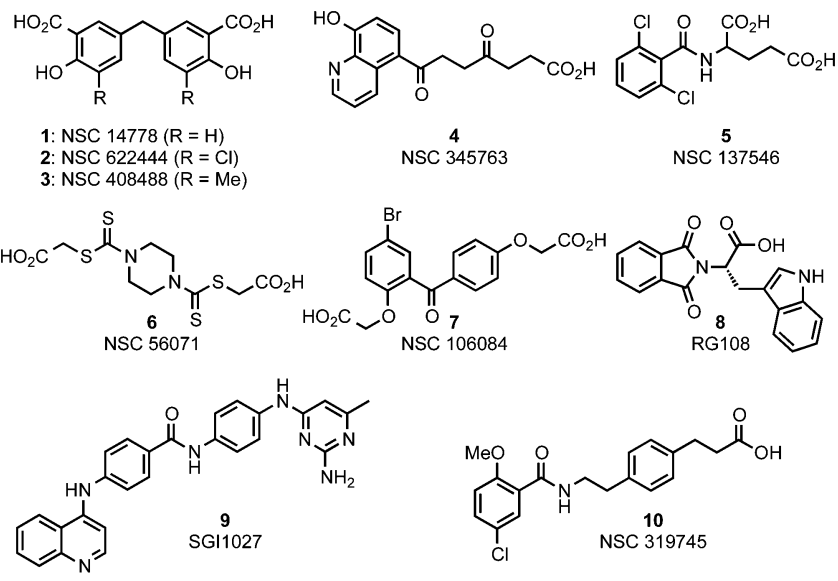

Fig. 1 Structure of selected non-nucleoside small-molecule inhibitors of DNMTs.
In 2010, Medina-Franco and Lyko reported the discovery of NSC 319745, a selective DNMT1 inhibitor (Fig. 1). ${ }^{35}$ This compound was identified following a virtual screening campaign of a 65000 compound collection from the NCI database using a homology model of the catalytic domain of human DNMT1. Using a biochemical assay, a residual enzymatic activity of $66 \%$ and $128 \%$ was measured against DNMT1 and DNMT3B, respectively, in the presence of $100 \mu \mathrm{M}$ of NSC 319745. Because of its inhibitory activity against DNMT1 and its structural features, NSC 319745 represents an attractive starting point for hit-to-lead programs. To the best of our knowledge, structure-activity-relationship (SAR) studies on this compound have never been reported.

We report herein the synthesis of NSC 319745 and the preparation of 29 analogues of this molecule. The inhibitory activity of these compounds against human DNMT1 and DNMT3A was measured and for the most potent compounds, the apparent $\mathrm{EC}_{50}$ was calculated. The compounds were also tested against the histone methyltransferases EZH2 and DOT1L to evaluate their selectivity against other SAM-dependent enzymes. The effect of the most potent inhibitors on the methylation level in MDA-MB-231 cells was explored and molecular docking studies have been performed to propose a mode of binding for this series.

\section{Results and discussion}

\section{Chemistry}

To initiate our medicinal chemistry efforts, we began by resynthesizing NSC 319745 . This compound was easily prepared from bromophenethylamine $\mathbf{1 1}$ using the synthetic sequence illustrated in Scheme 1. Protection of the amine 11 followed by Heck reaction with methyl acrylate and hydrogenation of the alkene furnished phenylpropionate 12. Removal of the BOC protecting group followed by amide formation using benzoyl chloride $\mathbf{1 4}$ and ester saponification gave NSC 319745 (10).

We then utilized this synthetic route to introduce different left-hand side aryl groups on the molecule (Scheme 2, compounds 20 to 27), to shorten the left-hand side alkyl chain (compounds 28 and 29) and to install a methyl group at the $\beta$

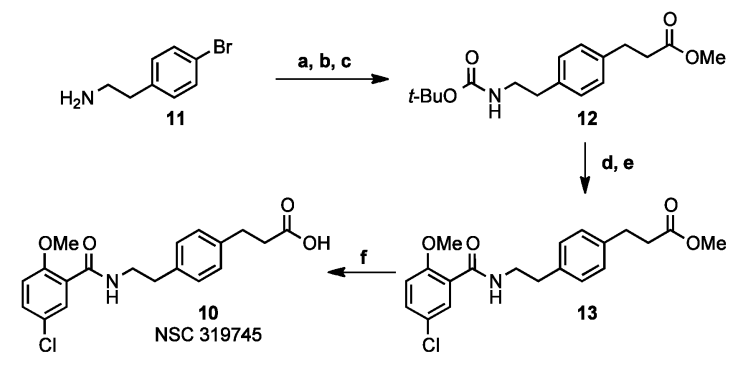

Scheme 1 Synthesis of NSC 319745. Reagents and conditions: (a) $\mathrm{BOC}_{2} \mathrm{O}, \mathrm{Et}_{3} \mathrm{~N}, \mathrm{i}-$ PrOH, r.t., $2 \mathrm{~h}, 93 \%$; (b) methyl acrylate, $\left(\mathrm{PPh}_{3}\right)_{2} \mathrm{PdCl}_{2}, \mathrm{LiCl}, \mathrm{Et}_{3} \mathrm{~N}$, DMF, microwave, $130{ }^{\circ} \mathrm{C}, 3 \mathrm{~h}, 58 \%$; (c) $\mathrm{H}_{2}, \mathrm{Pd} / \mathrm{C}$, $\mathrm{MeOH}$, r.t., 3 h, $98 \%$; (d) $\mathrm{CF}_{3} \mathrm{CO}_{2} \mathrm{H}, \mathrm{CH}_{2} \mathrm{Cl}_{2}$, r.t., 3 h, 95\%; (e) 5-chloro-2-methoxybenzoyl chloride (14), $\mathrm{Et}_{3} \mathrm{~N}, \mathrm{CH}_{2} \mathrm{Cl}_{2}$, r.t., 3 h, 87\%; (f) $\mathrm{LiOH}, \mathrm{THF}$, r.t., o.n., $87 \%$. 


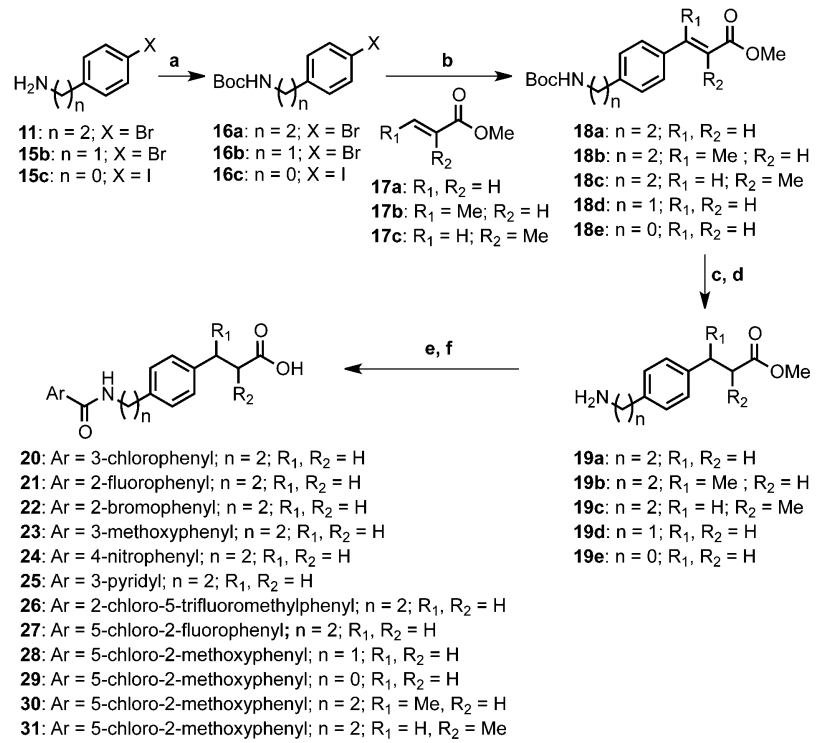

Scheme 2 General synthetic sequence used for the preparation of analogues 20 to 31. Reagents and conditions: (a) $\mathrm{BOC}_{2} \mathrm{O}, \mathrm{Et}_{3} \mathrm{~N}$, i-PrOH, r.t., 2 h, 79-93\%; (b) acrylate 17a-c, $\left(\mathrm{PPh}_{3}\right)_{2} \mathrm{PdCl}_{2}, \mathrm{LiCl}, \mathrm{Et}_{3} \mathrm{~N}, \mathrm{DMF}$, microwave, $130{ }^{\circ} \mathrm{C}, 3 \mathrm{~h}, 29-60 \%$; (c) $\mathrm{H}_{2}, \mathrm{Pd} / \mathrm{C}, \mathrm{MeOH}$, r.t., 3 h; (d) $\mathrm{CF}_{3} \mathrm{CO}_{2} \mathrm{H}, \mathrm{CH}_{2} \mathrm{Cl}_{2}$, r.t., 3 h, 79-94\% after 2 steps; (e) $\mathrm{ArCOCl}, \mathrm{Et}_{3} \mathrm{~N}, \mathrm{CH}_{2} \mathrm{Cl}_{2}$, r.t., 53-94\%; (f) LiOH, THF, r.t., o.n., 70-95\%.

and $\alpha$ positions of the right hand side carboxylic acid group (compounds 30 and 31).

The unsaturated analogue of NSC 319745 (compound 32) was then prepared by simply omitting the hydrogenation step from the general synthetic sequence (Scheme 3).

To study the importance of the amide $\mathrm{N}-\mathrm{H}$, we next prepared the $N$-methyl amide 33 by performing a chemo-selective methylation reaction on $\mathbf{1 3}$ followed by saponification of the ester (Scheme 4).

To evaluate potential acid surrogates, compounds 34 to 37 were prepared by amidation reaction of $\mathbf{1 0}$ using TBTU as the coupling agent (Scheme 5).

Introduction of modifications on the right-hand side propionic acid chain was performed by reacting benzoyl chloride 14 with different amines (Scheme 6).

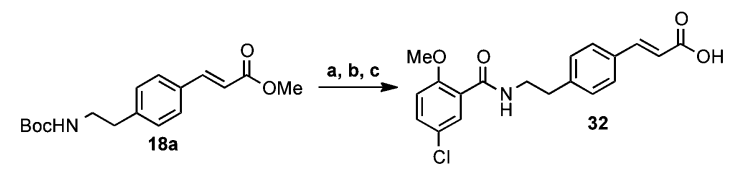

Scheme 3 Synthesis of cinnamic acid 32. Reagents and conditions: (a) $\mathrm{CF}_{3} \mathrm{CO}_{2} \mathrm{H}$, $\mathrm{CH}_{2} \mathrm{Cl}_{2}$, r.t., 3 h, 85\%; (b) 5-chloro-2-methoxybenzoyl chloride, $\mathrm{Et}_{3} \mathrm{~N}_{1} \mathrm{CH}_{2} \mathrm{Cl}_{2}$, r.t., $60 \%$; (c) LiOH, THF, r.t., o.n., $95 \%$.

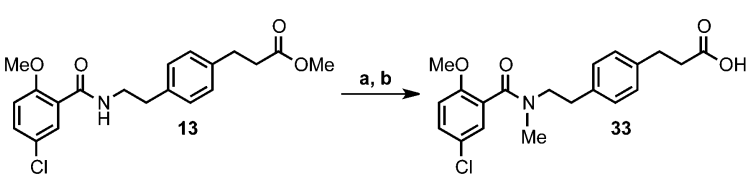

Scheme 4 Synthesis of $\mathrm{N}$-methyl amide 33. Reagents and conditions: (a) $\mathrm{NaH}$, DMF, $0{ }^{\circ} \mathrm{C}, 1 \mathrm{~h}$ then $\mathrm{Mel}$, r.t., o.n., $80 \%$; (b) LiOH, THF, r.t., o.n., $84 \%$.

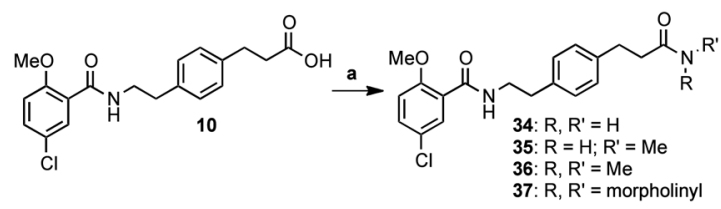

Scheme 5 Synthesis of amides 34-37. Reagents and conditions: (a) RR'NH, TBTU, i-Pr 2 NEt, DMF, r.t., 60-94\%.

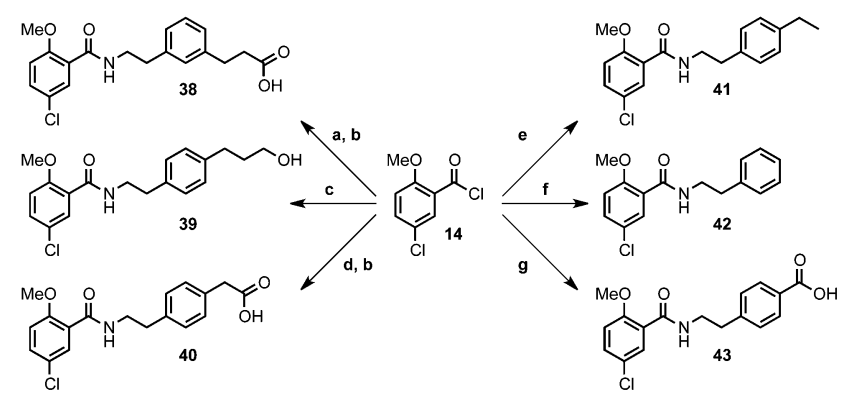

Scheme 6 Synthesis of compounds 38-43. Reagents and conditions: (a) 3-(3-(2aminoethyl)phenyl)propanoic acid methyl ester (44), $\mathrm{Et}_{3} \mathrm{~N}, \mathrm{CH}_{2} \mathrm{Cl}_{2}$, r.t., 83\%; (b) $\mathrm{LiOH}, \mathrm{THF}$, r.t., o.n., 61-98\%; (c) 3-(4-(2-aminoethyl)phenyl)propan-1-ol (45), $\mathrm{Et}_{3} \mathrm{~N}$, $\mathrm{CH}_{2} \mathrm{Cl}_{2}$, r.t., $27 \%$; (d) (2-aminoethyl)phenylacetic acid ethyl ester (46), $\mathrm{Et}_{3} \mathrm{~N}$, $\mathrm{CH}_{2} \mathrm{Cl}_{2}$, r.t., 83\%; (e) 4-ethylphenethylamine (47), $\mathrm{Et}_{3} \mathrm{~N}, \mathrm{CH}_{2} \mathrm{Cl}_{2}$, r.t., $64 \%$; (f) phenethylamine, $\mathrm{Et}_{3} \mathrm{~N}, \mathrm{CH}_{2} \mathrm{Cl}_{2}$, r.t., $62 \%$; (g) 4-(2-aminoethyl)benzoic acid hydrochloride, $\mathrm{NaOH}$, $\mathrm{THF}$, r.t., $56 \%$.

Using this approach, the chain was moved to the meta position (compound 38), shortened by one and two methylene units (compounds $\mathbf{4 0}$ and 43), or completely removed (compound 42). Compounds where the acid is reduced to the alcohol (compound 39) or deleted (compound 41) were also prepared.

We next proceeded with the introduction of an oxygen atom in the propionic acid chain by coupling 4-hydroxyphenethylamine 48 with benzoyl chloride 14 (Scheme 7). Compound 49 was then subjected to an alkylation reaction with methyl bromoacetate to provide the corresponding ester which was saponified to afford the acid $\mathbf{5 0 .}$

A simple variation of the previous synthetic sequence allowed the introduction of a carboxylic acid group to the central linker (compound 54, Scheme 8).

We next focused our attention on the benzamide moiety of NSC 319745 and prepared the reverse amide 58 (Scheme 9). This compound was accessed starting from acid $\mathbf{5 5}$ by formation of a benzyl ester followed by a Heck reaction with methyl acrylate to give the cinnamate 56. Saturation of the double bond and

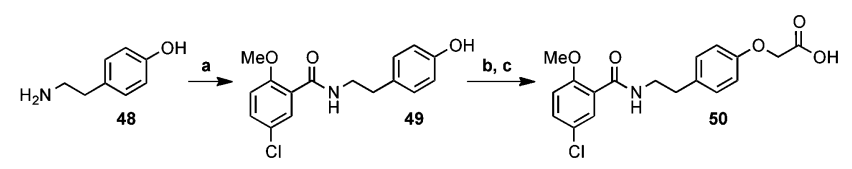

Scheme 7 Synthesis of compounds 49 and 50. Reagents and conditions: (a) 14 $\mathrm{Et}_{3} \mathrm{~N}, \mathrm{CH}_{2} \mathrm{Cl}_{2}$, r.t., 57\%; (b) methyl bromoacetate, $\mathrm{K}_{2} \mathrm{CO}_{3}, \mathrm{MeCN}$, reflux, $48 \%$; (c) LiOH, THF, r.t., o.n., $93 \%$. 


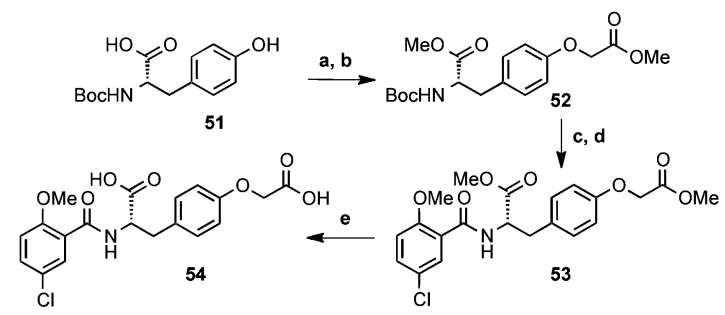

Scheme 8 Synthesis of compound 54. Reagents and conditions: (a) $\mathrm{Mel}, \mathrm{K}_{2} \mathrm{CO}_{3}$, DMF, r.t., o.n., 88\%; (b) methyl bromoacetate, $\mathrm{K}_{2} \mathrm{CO}_{3}, \mathrm{MeCN}$, reflux, $2 \mathrm{~h}, 63 \%$; (c) $\mathrm{CF}_{3} \mathrm{CO}_{2} \mathrm{H}, \mathrm{CH}_{2} \mathrm{Cl}_{2}$, r.t., 3 h, $98 \%$; (d) 14, $\mathrm{Et}_{3} \mathrm{~N}, \mathrm{CH}_{2} \mathrm{Cl}_{2}$, r.t., 88\%; (e) $\mathrm{LiOH}$, THF, r.t., o.n., $80 \%$.

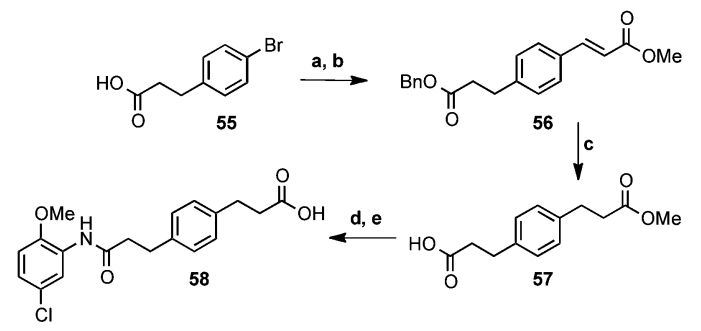

Scheme 9 Synthesis of reverse amide 58. Reagents and conditions: (a) BnOCOCl, $\mathrm{Et}_{3} \mathrm{~N}, \mathrm{DMAP}, \mathrm{CH}_{2} \mathrm{Cl}_{2}, 0{ }^{\circ} \mathrm{C}, 30 \mathrm{~min}, 70 \%$; (b) methyl acrylate, $\left(\mathrm{PPh}_{3}\right)_{2} \mathrm{PdCl}_{2}, \mathrm{LiCl}$, $\mathrm{Et}_{3} \mathrm{~N}$, DMF, microwave, $130{ }^{\circ} \mathrm{C}, 3$ h, 54\%; (c) $\mathrm{H}_{2}, \mathrm{Pd} / \mathrm{C}, \mathrm{MeOH}$, r.t., 3 h, $99 \%$; (d) 5-chloro-2-methoxyaniline (59), TBTU, i- $\mathrm{Pr}_{2} \mathrm{NEt}$, DMF, r.t., o.n., 36\%; (e) LiOH, THF, r.t., o.n., $74 \%$.

deprotection of the benzyl ester were performed simultaneously under hydrogenation conditions to give the intermediate $\mathbf{5 7}$, which was then coupled with aniline $\mathbf{5 9}$ to provide the final compound 58.

Finally, the analogue of NSC 319745 having a reduced amide was prepared (compound 60, Scheme 10) via a reductive amination reaction between amine 19a and 5-chloro-2-methoxybenzaldehyde $\mathbf{6 1}$.

\section{DNMT1 and DNMT3A inhibitory activity}

Since NSC 319745 was reported to inhibit DNMT1, we started by evaluating the inhibitory activity of the resynthesized NSC 319745 (compound 10) and its 29 analogues against full-length DNMT1 using a ${ }^{3} \mathrm{H}$-methyl group incorporation assay (Fig. 2).

The results show that all the compounds give less than $20 \%$ inhibition against DNMT1 compared to $100 \%$ inhibition by reference compound SGI1027. The compounds that gave the highest inhibition are the 4-nitrobenzamide 24 (14\%), the phenol 49 (16\%), and the acid 50 (15\%). Contrary to previous<smiles>COC(=O)CCc1ccc(CCN)cc1</smiles>

Scheme 10 Synthesis of secondary amine 60. Reagents and conditions: (a) 5-chloro-2-methoxybenzaldehyde (61), $\mathrm{NaBH}_{3} \mathrm{CN}, \mathrm{MeOH}, \mathrm{AcOH}$, r.t., o.n., 18\%; (b) $\mathrm{LiOH}$, THF, r.t., o.n., $69 \%$.

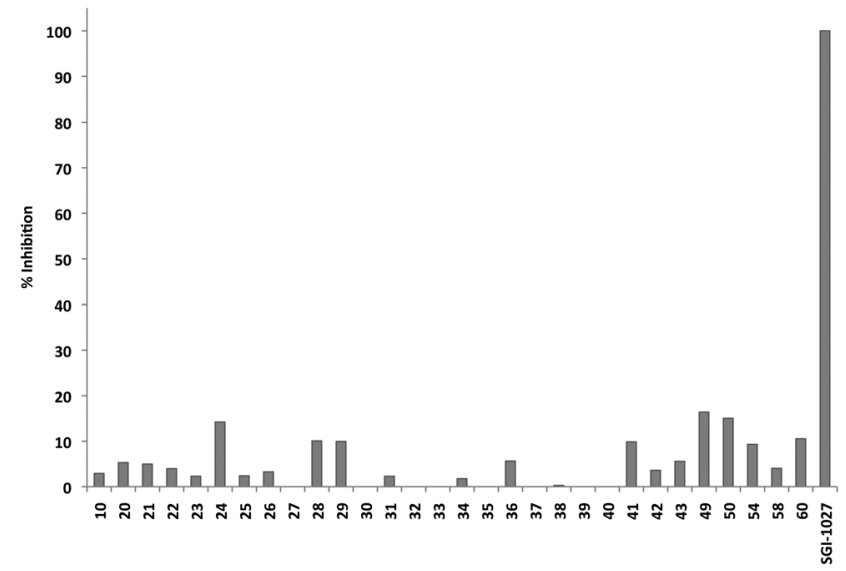

Compound number

Fig. 2 Inhibitory activity against DNMT1 expressed as \% inhibition of methylation in the presence of $100 \mu \mathrm{M}$ of inhibitors. SGI-1027 was used as a reference compound.

reports, the resynthesized NSC 319745 (compound 10) showed no significant inhibitory activity against DNMT1 (ca. 2.9\%). To confirm this result, we retested compound 10 at $50 \mu \mathrm{M}, 100 \mu \mathrm{M}$, and $200 \mu \mathrm{M}$ and observed no detectable inhibition of DNMT1 activity. These results indicate that NSC 319745 is not an inhibitor of DNMT1 in our enzymatic test.

The activity of the compounds was then measured against DNMT3A at $10 \mu \mathrm{M}$ and $100 \mu \mathrm{M}$ using a nonradioactive assay based on fluorescence detection using the human catalytic DNMT3A (Fig. 3). ${ }^{36}$ Interestingly, compounds 24, 26, 28, 29, 49, 50, and 54 showed greater than $60 \%$ inhibition at $100 \mu \mathrm{M}$. All of these compounds, except 26, also showed more than $13 \%$ inhibition at $10 \mu \mathrm{M}$. Resynthesized NSC 319745 (10) showed negligible inhibitory activity against DNMT3A at both concentrations, in agreement with previous literature reports indicating that NSC 319745 does not inhibit DNMT3B.

A complete inhibition curve was measured for the compounds that showed greater than $60 \%$ inhibitory activity

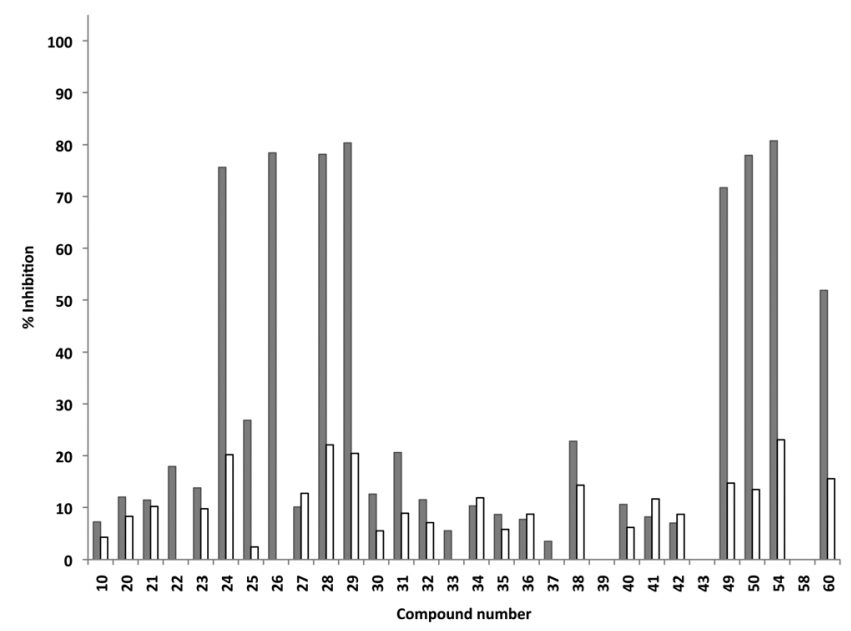

Fig. 3 Inhibitory activity against DNMT3A expressed as \% inhibition of methylation in the presence of $100 \mu \mathrm{M}$ (gray bars) and $10 \mu \mathrm{M}$ (white bars) of inhibitors. 


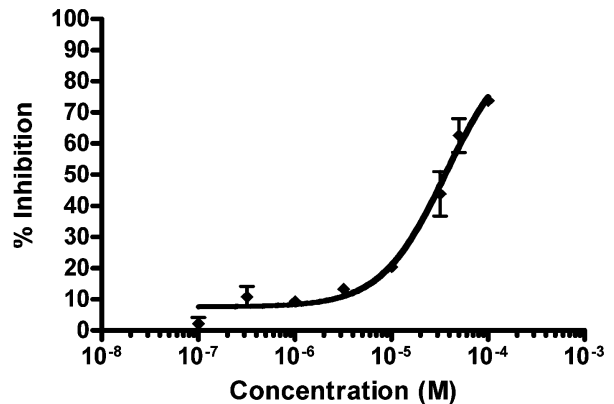

Fig. 4 Complete inhibition curve for compound 49 against DNMT3A. The experiment was run twice in duplicate. The mean value is reported with the standard error. A confidence interval of $95 \%$ and $r^{2}=0.97$ were calculated.

against DNMT3A at $100 \mu \mathrm{M}$. An apparent $\mathrm{EC}_{50}$ of $36 \mu \mathrm{M}$ was calculated for compound 49 (Fig. 4). Complete inhibition could not be reached for the other compounds at concentrations up to $100 \mu \mathrm{M}$, thus making the determination of $\mathrm{EC}_{50}$ not possible.

In order to verify the selectivity of the prepared compounds against other SAM-dependent methyltransferases, we tested them against EZH2 and DOT1L. EZH2 (Enhancer of Zeste homolog 2) catalyzes the methylation on lysine 27 of histone 3 (H3K27). ${ }^{37}$ Vire et al. have demonstrated that EZH2 serves as a recruitment platform for DNMTs, thus suggesting a connection between these two epigenetic enzymes in gene silencing. ${ }^{38}$ DOT1L (Disruptor of Telomeric silencing) is an enzyme that performs the methylation on lysine 79 of histone 3 (H3K79). ${ }^{39}$ Using a ${ }^{3} \mathrm{H}-\mathrm{SAM}$ assay, no inhibition of EZH2 or DOT1L could be observed at concentrations up to $80 \mu \mathrm{M}$, indicating the specificity of the compounds against DNA methylation.

\section{Molecular modeling}

Molecular docking of $\mathbf{4 9}$ was performed using the Forecaster ${ }^{\circledR}$ platform $^{40}$ from Molecular Forecaster to establish its binding mode using the crystal structure of the human catalytic Dnmt3A/3L complex (PDB: 2QRV). The results from the docking show a linear conformation for inhibitor 49 (green in Fig. 5) with the amide group being in the expected trans conformation.

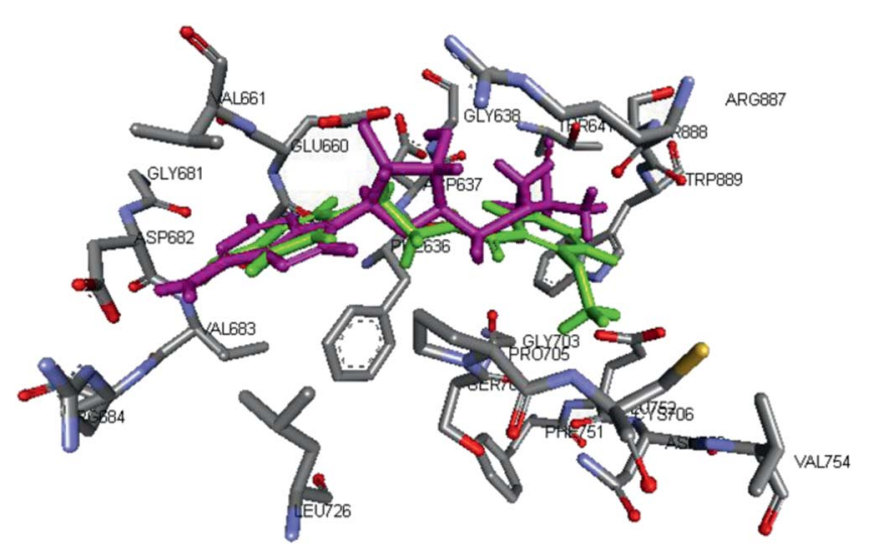

Fig. 5 Docking of $\mathbf{4 9}$ in DNMT3A (PDB: 2QRV) using Forecaster ${ }^{\circledR}$ (49 in green, $\mathrm{SAH}$ in magenta).
The ortho methoxy group is found to be oriented in the same direction as the amide carbonyl group oxygen. When the binding of 49 is compared with that of SAH (magenta in Fig. 5), we observe an overlap of the phenol moiety of 49 with the SAH adenine group. The flexible chain of the inhibitor extends inside the binding pocket in the same orientation as the homocysteine chain of SAH. These similarities in binding mode seem to suggest that inhibitor 49 binds in the SAM/SAH binding site.

\section{Cellular activity}

The impact of the most potent DNMT3A inhibitors on the methylation level was evaluated in MDA-MB-231 breast cancer cells using a luminometric methylation assay. The global methylation level was determined in the presence of $100 \mu \mathrm{M}$ and $200 \mu \mathrm{M}$ inhibitors using a methylation sensitive restriction assay (HpaII/Msp1) followed by luminometric (LUMA) determination of cleavage by HpaII (sensitive to methylation at $\mathrm{CC}^{\mathrm{m}} \mathrm{GG}$ ) versus $\mathrm{Msp} 1$ (insensitive to $\mathrm{CC}^{\mathrm{m}} \mathrm{GG}$ methylation). Compounds that were not sufficiently soluble in aqueous media (compounds 28 and 29) or that were cytotoxic (compounds 24, 26 and 49) were not tested. Compounds 50 and 54 were thus selected for cell studies based on potency, solubility and absence of cytotoxicity (Fig. 6).

To our great disappointment, compound $\mathbf{5 0}$ induced no significant reduction of the methylation level at $100 \mu \mathrm{M}$ and $200 \mu \mathrm{M}$. Similarly, when the cells were incubated in the presence of compound 54, no effect on the methylation level could be detected at $100 \mu \mathrm{M}$ while only a minor reduction was observed at $200 \mu \mathrm{M}$. Although compounds $\mathbf{5 0}$ and $\mathbf{5 4}$ were effective in inhibiting DNA methyltransferase activity in vitro, they did not show significant activity in cells as far as global DNA measurements are concerned in contrast to the classical DNA methylation inhibitor 5-azaC which dramatically reduced DNA methylation in the same experiment. There could be several explanations for the discrepancy between in vitro and in vivo potencies of these agents. First, there might be permeability issues that reduce the

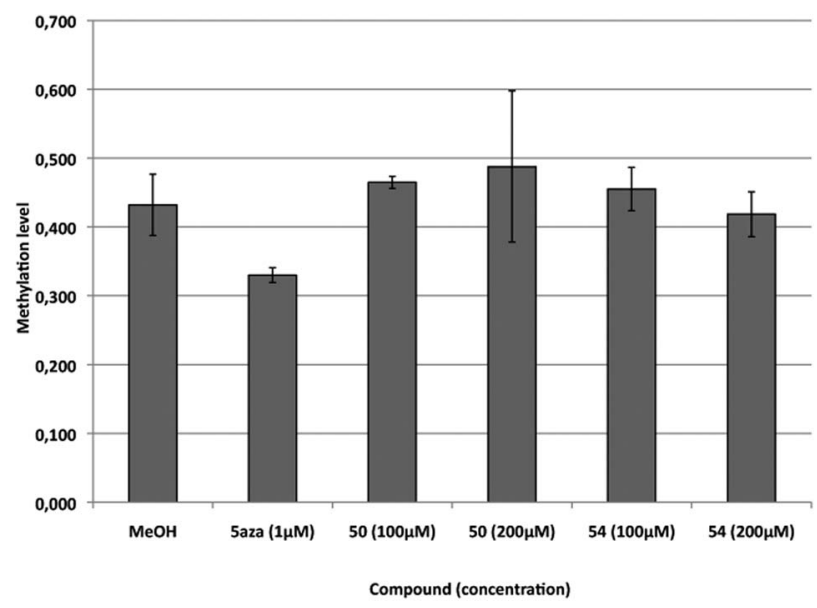

Fig. 6 Global methylation level of MDA-MB-231 cells measured by luminometric assay (LUMA). Data are presented as mean of triplicate. 5-Azacytidine was used as a reference compound at $1 \mu \mathrm{M}$. 
availability of the drug in the cell or in the nucleus. The second possibility is that in contrast to 5-azaC which is incorporated into DNA and trap the DNMTs, the compounds tested are catalytic inhibitors of DNMTs and it is possible that the level of inhibition is insufficient to block DNA methylation during replication. We have previously shown that inhibition of DNMT results in inhibition of DNA replication which in turn reduces the level of substrate for DNA methylation and thus the impact of DNMT inhibition on methylation of newly synthesized DNA. ${ }^{\mathbf{4 1}}$ Further modifications of the compounds are possibly required to increase potency and permeability in order to achieve effective inhibition of DNA methylation during DNA synthesis in living cells.

\section{Conclusion}

The identification of small-molecules that modulate epigenetic processes can open new avenues for the treatment of cancer, ${ }^{42}$ mental health diseases, and psychopathology disorders. ${ }^{43}$ Drugs that target DNMTs could also increase the options for treatment in the context of combination therapy. ${ }^{\mathbf{4 4}}$ We performed the resynthesis of NSC 319745 (a compound discovered by virtual screening against DNMT1) and 29 analogues and demonstrated that, contrary to previous reports, NSC 319745 is not a DNMT inhibitor. All the analogues of NSC 319745 showed less than $20 \%$ inhibition against DNMT1 at $100 \mu \mathrm{M}$. Seven compounds were found to significantly inhibit DNMT3A (compounds 24, 26, 28, 29, 49, 50, and 54). An inhibition curve against DNMT3A was measured for compound 49, giving an apparent $\mathrm{EC}_{50}$ of $36 \mu \mathrm{M}$. Molecular docking studies suggest that compound 49 binds in the SAM pocket. For all the compounds prepared, no activity was detected against EZH2 and DOT1L, two lysine histone methyltransferases. A moderate reduction of the methylation level in MDA-MB-231 cells was observed for compound $\mathbf{5 4}$ at $200 \mu \mathrm{M}$. Compounds 49 and $\mathbf{5 4}$ are two small-molecule inhibitors of DNMT3 that could represent a potential new starting point for lead optimization programs. Medicinal chemistry activities on this series to generate permeable and more potent compounds are underway in our laboratories and results will be reported in due course.

\section{Experimental section}

\section{Chemistry}

General methods. All reactions were run under an argon atmosphere in non flame dried glassware. Unless otherwise stated, commercial reagents were used without further purification. Nuclear magnetic resonance spectra were recorded on a Bruker Avance-III $300 \mathrm{MHz}$ spectrometer. Chemical shifts for ${ }^{1} \mathrm{H}$-NMR spectra are recorded in parts per million from tetramethylsilane with the solvent resonance as the internal standard. Data are reported as follows: chemical shift, multiplicity ( $\mathrm{s}=$ singlet, $\mathrm{d}=$ doublet, $\mathrm{t}=$ triplet, $\mathrm{q}=$ quartet, $\mathrm{m}=$ multiplet), coupling constant $J$ in $\mathrm{Hz}$, integration, and assignment. Chemical shifts for ${ }^{13} \mathrm{C}$ spectra are recorded in parts per million from tetramethylsilane using the central peak of deuterochloroform (77.00 ppm) as the internal standard. All ${ }^{13} \mathrm{C}-\mathrm{NMR}$ spectra were obtained with complete proton decoupling. Purity of tested compounds was determined by HPLC analysis on a Beckman Gold HPLC system using a C18 column and acetonitrile (containing $0.01 \%$ of TFA) and water (containing $0.01 \%$ of TFA) as the mobile phase. The purity of all final compounds is greater than 95\%. Compounds 41, 42, 43, 49, and 50 were synthesized following a literature procedure. ${ }^{45}$

$\mathrm{N}$-BOC protection: general procedure. In a round bottom flask, $10 \mathrm{mmol}$ of amine 11 or $\mathbf{1 5 b}$ and c (1.0 eq.), $10 \mathrm{mmol}$ of $\mathrm{BOC}_{2} \mathrm{O}$ (1.0 eq.) and $20 \mathrm{mmol}$ of $\mathrm{Et}_{3} \mathrm{~N}$ (2.0 eq.) in $50 \mathrm{~mL}$ of $\mathrm{i}$-PrOH were stirred at r.t. Progress of the reaction was monitored by TLC (hexane-EtOAc, $4: 1$ ). After reaction completion, the solvent was evaporated under vacuum. The residue was purified by flash column chromatography (hexane-EtOAc, $10: 1)$ to afford the $N$-BOC amines $16 \mathbf{a}-\mathbf{c}$.

Heck reaction: general procedure. A mixture of $16 \mathrm{a}-\mathrm{c}$ (1.0 mmol, 1.0 eq.), LiCl (2.0 mmol, 2.0 eq.) and $\mathrm{PdCl}_{2}\left(\mathrm{PPh}_{3}\right)_{2}$ (0.05 mmol, 0.05 eq.) in DMF (4 mL) in a microwave vial $(5 \mathrm{~mL})$ was degassed by bubbling argon through the solution for 10 min. $\mathrm{Et}_{3} \mathrm{~N}$ (2 mmol, 2.0 eq.) and methyl acrylate 17a-c (1.25 mmol, 1.25 eq.) were added, and the mixture was degassed again for $5 \mathrm{~min}$. Then, the sealed vial was stirred in a microwave at $130{ }^{\circ} \mathrm{C}$ for $3 \mathrm{~h}$. The reaction mixture was diluted with EtOAc and washed with aq. sat. solution of $\mathrm{NaHCO}_{3}$. The organic layer was separated, dried over anhydrous $\mathrm{Na}_{2} \mathrm{SO}_{4}$, filtered and concentrated under vacuum. The crude mixture was purified by flash column chromatography (hexane-EtOAc, $8: 1$ ) to afford compounds 18a-e.

Hydrogenation: general procedure. A solution of the substrate 18a-e in $\mathrm{MeOH}(0.06 \mathrm{M})$ was stirred at room temperature over a $10 \% \mathrm{Pd} / \mathrm{C}$ catalyst $(10 \% \mathrm{w} / \mathrm{w})$ under a hydrogen atmosphere for $3 \mathrm{~h}$. After reaction completion, the mixture was filtered through a pad of celite and washed with $\mathrm{CH}_{2} \mathrm{Cl}_{2}$. The collected organic phase was evaporated under vacuum. The crude product was used directly in the next step without further purification.

$N$-BOC deprotection: general procedure. $\mathrm{CF}_{3} \mathrm{CO}_{2} \mathrm{H}$ (50 eq.) was added dropwise to a $0{ }^{\circ} \mathrm{C} 0.25 \mathrm{M}$ anhydrous $\mathrm{CH}_{2} \mathrm{Cl}_{2}$ solution of the $N$-BOC protected compound (1.0 eq.) obtained from the previous step. The resulting mixture was stirred for $3 \mathrm{~h}$ at r.t. and the solvent was removed under reduced pressure. The residue was taken up in $\mathrm{CH}_{2} \mathrm{Cl}_{2}$ and washed twice with aq. sat. solution of $\mathrm{NaHCO}_{3}$. The organic layer was separated, dried over anhydrous $\mathrm{Na}_{2} \mathrm{SO}_{4}$, filtered and concentrated under vacuum. The product 19a-e was obtained as a free base and was used directly in the next step without further purification.

Amide synthesis: general procedure. A $0.4 \mathrm{M}$ anhydrous $\mathrm{CH}_{2} \mathrm{Cl}_{2}$ solution of the benzoyl chloride (1.1 eq.) was added dropwise to a $0{ }^{\circ} \mathrm{C}$ anhydrous $0.2 \mathrm{M} \mathrm{CH}_{2} \mathrm{Cl}_{2}$ solution of amine 19a-e (1.0 eq.) and $\mathrm{Et}_{3} \mathrm{~N}$ (2.0 eq.). The resulting mixture was stirred at r.t. After completion of the reaction, as indicated by TLC analysis, the mixture was diluted with $\mathrm{CH}_{2} \mathrm{Cl}_{2}$ and washed with brine. The organic layer was separated, dried over anhydrous $\mathrm{Na}_{2} \mathrm{SO}_{4}$, filtered and concentrated under vacuum. The residue was purified by flash column chromatography $(1 \%$ $\mathrm{MeOH} / \mathrm{CH}_{2} \mathrm{Cl}_{2}$ ), providing the corresponding amide. 
Saponification: general procedure. To a $0{ }^{\circ} \mathrm{C} 0.05 \mathrm{M}$ THF solution of the methyl ester (1.0 eq.) obtained in the previous step was added a $1 \mathrm{M}$ aqueous solution of $\mathrm{LiOH}$ (5.0 eq.). The resulting mixture was stirred at r.t. overnight. The reaction mixture was then diluted with $1 \mathrm{M} \mathrm{NaOH}$ and washed twice with ether. The water phase was separated and carefully acidified with conc. $\mathrm{HCl}$ until $\mathrm{pH} \sim 3$ was reached. The crude product was extracted three times with $\mathrm{CH}_{2} \mathrm{Cl}_{2}$. The organic fraction was dried over anhydrous $\mathrm{Na}_{2} \mathrm{SO}_{4}$, filtered and concentrated under vacuum. The residue was purified by flash column chromatography (5-10\% $\mathrm{MeOH} / \mathrm{CH}_{2} \mathrm{Cl}_{2}$ ) providing the corresponding acid 10 and 20-31.

3-(4-(2-(5-Chloro-2-methoxybenzamido)ethyl)phenyl)-propanoic acid 10. $R_{\mathrm{f}} 0.3\left(5 \% \mathrm{MeOH} / \mathrm{CH}_{2} \mathrm{Cl}_{2}\right) .{ }^{1} \mathrm{H}-\mathrm{NMR}(300 \mathrm{MHz}$, $\left.\mathrm{CDCl}_{3}\right): \delta 10.94\left(\mathrm{~s}(\mathrm{br}), 1 \mathrm{H}, \mathrm{CO}_{2} \mathrm{H}\right), 8.15(\mathrm{~d}, J=2.7 \mathrm{~Hz}, 1 \mathrm{H}, \mathrm{Ph})$, 7.86 (s (br), 1H, NH), 7.33 (dd, $J=8.7,2.7 \mathrm{~Hz}, 1 \mathrm{H}, \mathrm{Ph}), 7.17$ (s (br), 4H, Ph), 6.82 (d, J=8.7 Hz, 1H, Ph), 3.74-3.68 (m, 5H, Me, $\left.\mathrm{CH}_{2}\right), 2.97-2.84\left(\mathrm{~m}, 4 \mathrm{H}, 2 \times \mathrm{CH}_{2}\right), 2.67\left(t, J=7.6 \mathrm{~Hz}, 2 \mathrm{H}, \mathrm{CH}_{2}\right)$. ${ }^{13} \mathrm{C}-\mathrm{NMR}\left(75 \mathrm{MHz}, \mathrm{CDCl}_{3}\right.$ ): $\delta$ 177.9, 164.1, 156.0, 138.5, 137.1, 132.3, 131.9, 129.1, 128.5, 126.7, 122.8, 112.8, 56.1, 40.9, 35.6, 35.1, 30.2. HPLC: $R_{\mathrm{t}}=12.9 \mathrm{~min}, 99.9 \%$.

5-Chloro- $\boldsymbol{N}$-(4-hydroxyphenethyl)-2-methoxybenzamide 49. $R_{\mathrm{f}} 0.4\left(5 \% \mathrm{MeOH} / \mathrm{CH}_{2} \mathrm{Cl}_{2}\right) .{ }^{1} \mathrm{H}-\mathrm{NMR}\left(300 \mathrm{MHz}, \mathrm{CDCl}_{3}\right): \delta 8.23(\mathrm{~d}$, $J=2.7 \mathrm{~Hz}, 1 \mathrm{H}, \mathrm{Ph}), 7.94(\mathrm{~s}(\mathrm{br}), 1 \mathrm{H}, \mathrm{NH}), 7.42(\mathrm{dd}, J=8.7,2.7 \mathrm{~Hz}$, $1 \mathrm{H}, \mathrm{Ph}), 7.16$ (d, $J=8.4 \mathrm{~Hz}, 2 \mathrm{H}, \mathrm{Ph}), 6.89(t, J=8.7 \mathrm{~Hz}, 3 \mathrm{H}, \mathrm{Ph})$, $3.83(\mathrm{~s}, 3 \mathrm{H}, \mathrm{Me}), 3.80-3.74\left(\mathrm{~m}, 2 \mathrm{H}, \mathrm{CH}_{2}\right), 2.89(t, J=6.6 \mathrm{~Hz}, 2 \mathrm{H}$, $\mathrm{CH}_{2}$ ). ${ }^{13} \mathrm{C}-\mathrm{NMR}\left(75 \mathrm{MHz}, \mathrm{CDCl}_{3}\right.$ ): $\delta$ 164.1, 156.0, 154.6, 132.4, 132.0, 130.9, 130.0, 126.8, 122.8, 115.5, 112.8, 56.2, 41.2, 34.6. HPLC: $R_{\mathrm{t}}=12.2 \mathrm{~min}, 95.3 \%$

(S)-3-(4-(Carboxymethoxy)phenyl)-2-(5-chloro-2-methoxybenzamido)propanoic acid 54. $R_{\mathrm{f}} 0.3\left(5 \% \mathrm{MeOH} / \mathrm{CH}_{2} \mathrm{Cl}_{2}\right)$. ${ }^{1} \mathrm{H}-\mathrm{NMR}\left(300 \mathrm{MHz}, \mathrm{CD}_{3} \mathrm{OD}\right): \delta 8.60(\mathrm{~d}, J=6.9 \mathrm{~Hz}, 1 \mathrm{H}, \mathrm{NH}), 7.95$ (d, $J=2.7 \mathrm{~Hz}, 1 \mathrm{H}, \mathrm{Ph}), 7.51(\mathrm{dd}, J=9.0,2.7 \mathrm{~Hz}, 1 \mathrm{H}, \mathrm{Ph}), 7.21-$ $7.16(\mathrm{~m}, 3 \mathrm{H}, \mathrm{Ph}), 6.93$ (d, $J=8.7 \mathrm{~Hz}, 2 \mathrm{H}, \mathrm{Ph}), 4.89-4.85(\mathrm{~m}, 1 \mathrm{H})$, 4.68 (s, 2H, $\mathrm{CH}_{2}$ ), 3.88 (s, 3H, Me), 3.26-3.21 (m, 2H, $\left.\mathrm{CH}_{2}\right) \cdot{ }^{13} \mathrm{C}-$ NMR (75 MHz, $\left.\mathrm{CD}_{3} \mathrm{OD}\right): \delta$ 174.4, 165.8, 158.7, 158.1, 134.0, $131.8,131.7,130.6,127.3,123.6,115.7,115.1$, 65.9, 57.2, 55.4, 37.3. HPLC: $R_{\mathrm{t}}=11.1 \mathrm{~min}, 97.9 \%$.

\section{Biology}

DNMT1 inhibition assay. His-DNMT1 (182 kDa, human) was expressed and purified as described in ref. 29a. DNMT1 activity was measured by following the transfer of radioactively labeled methyl from SAM to a biotinylated oligonucleotide containing one hemimethylated CpG site as described in ref. 29b with some changes

In the Flashplate ${ }^{\mathrm{TM}}$ assay, the reaction was performed in a 10 $\mu \mathrm{L}$ total reaction volume in low volume NBS ${ }^{\mathrm{TM}}$ 384-well microplates (Corning), containing the tested compound (up to $1 \%$ DMSO), $1 \mu \mathrm{M}$ of a SAM/[methyl- $\left.{ }^{3} \mathrm{H}\right]$ SAM (3 TBq per mmol, PerkinElmer) mix in a ratio of 3-to-1 (isotopic dilution $1: 3$ ), $0.3 \mu \mathrm{M}$ of biotinylated hemimethylated DNA duplex (5'-GATmCGCmC GATG $m C$ G $m C$ GAAT $m C$ Gm $m$ CGAT $m C G A T G m C G A T-3^{\prime}$ and BIOT-5' ATCGCATCGATCGCGATTCGCGCATCGGCGATC-3'), and $90 \mathrm{nM}$ of DNMT1 in methylation buffer (20 mM HEPES pH 7.2, $1 \mathrm{mM}$ EDTA, $\left.50 \mathrm{mM} \mathrm{KCl,} 25 \mu \mathrm{g} \mathrm{mL}{ }^{-1} \mathrm{BSA}\right)$. The reaction was incubated at $37{ }^{\circ} \mathrm{C}$ for 2 hours. $8 \mu \mathrm{L}$ are then transferred into a streptavidin 96-well scintillant coated Flashplate ${ }^{\mathrm{TM}}$ (PerkinElmer) containing $190 \mu \mathrm{L}$ of $20 \mu \mathrm{M}$ SAH in $50 \mathrm{mM}$ Tris-HCl pH 7.4. The Flashplate ${ }^{\mathrm{TM}}$ was agitated at room temperature for 1 hour, washed three times with $200 \mu \mathrm{L}$ of $0.05 \%$ Tween ${ }^{\circledR}-20$ in $50 \mathrm{mM}$ Tris- $\mathrm{HCl} \mathrm{pH} 7.4$, and read in $200 \mu \mathrm{L}$ of $50 \mathrm{mM}$ Tris- $\mathrm{HCl}$ pH 7.4 on a TopCount NXT (PerkinElmer).

DNMT3A inhibition assay. The procedure described in ref. 36 was used on catalytic human DNMT3A. Briefly, a 5'-labelled biotin oligonucleotide is hybridized to its complementary strand labelled with 6-carboxyfluorescein at the $3^{\prime}$-end into a 384 well microplate (black Optiplates; Perkin Elmer) pre-coated with avidin. The duplex contains a unique CpG site overlapping with a restriction site of a methylation sensitive restriction enzyme. The human C-terminal DNMT3A (a.a. 623-912), produced as described in the literature, ${ }^{46}$ was added in each well (100 nM) and mixed with the chemical compounds at desired concentrations and freshly prepared SAM $(20 \mu \mathrm{M}$ final concentration) to start the reaction in a total volume of $50 \mu \mathrm{L}$. After 1 hour incubation at $37^{\circ} \mathrm{C}$ each well was washed three times with PBS, Tween-20 0.05\%, NaCl (500 mM) and three more times with PBST. Specific fluorescent signals were detected with the methylation-sensitive restriction enzyme HpyCH4IV (NEB) as described and measured on a Perkin Elmer Envision detector.

EZH2 inhibition assay. PRC2, biotinylated nucleosome (both prepared in-house), H3K27Me3 activator peptide (RKQLATKAARK(Me3)SAPATGGVKKP-NH ${ }_{2}$, New England Peptide, Gardner, MA) and compound (in DMSO) were incubated in $50 \mathrm{mM}$ Tris, pH 8.5, $5 \mathrm{mM} \mathrm{MgCl}_{2}, 1 \mathrm{mM}$ DTT, $70 \mu \mathrm{M}$ Brij-35, and $0.1 \mathrm{mg}$ $\mathrm{mL}^{-1}$ BSA for 30 minutes. Reaction was initiated by addition of ${ }^{3} \mathrm{H}$-SAM to final conditions of $5 \mathrm{nM}$ PRC2, $200 \mathrm{nM}$ nucleosome (concentration expressed as $\mathrm{H} 3)$, activator peptide $(3.6 \mu \mathrm{M})$ and $200 \mathrm{nM}{ }^{3} \mathrm{H}$-SAM in a total volume of $25 \mu \mathrm{L}$ in 384 well Greiner plates. For compound analysis, assays were ten point doseresponses with a final total DMSO of $0.8 \%(\mathrm{v} / \mathrm{v})$. Typically assays were run for 60 minutes with $<35 \%$ substrate turnover. After that, reaction assays were quenched by addition of $20 \mu \mathrm{L}$ of $2 \mathrm{mM}$ SAH and $200 \mathrm{mM}$ EDTA in $50 \mathrm{mM}$ Tris, $\mathrm{pH}$ 8.5. Reactions were transferred to streptavidin coated FlashPlates, incubated for 2 hours, aspirated, washed, and read on a TopCount.

DOT1L inhibition assay. Run in a manner similar to the EZH2 assay except that GST-DOT1L $\mathrm{L}_{1-416}$ (prepared in-house ${ }^{47}$ ) was used at a final concentration of $12 \mathrm{nM}$ enzyme, $30 \mathrm{nM}$ biotinylated oligonucleosome, $500 \mathrm{nM} 3 \mathrm{H}$-SAM and 30 minute reaction time course in a buffer consisting of $50 \mathrm{mM}$ Tris, $\mathrm{pH}$ 8.5, $5 \mathrm{mM} \mathrm{MgCl}_{2}, 1 \mathrm{mM}$ DTT, and $80 \mu \mathrm{M}$ Tween-20. Subsequent quench and work-up were as for EZH2.

Cell line and culture conditions. Breast MDA-MB-231 cells (\#HTB-231) were purchased from the American Type Culture Collection (ATCC, Manassas, Virginia). MDA-MB-231 cells were cultured in Dulbecco's modified Eagle's medium (Invitrogen). $2 \times 10^{6}$ MDA-MB-231 cells were plated the day before treatment on 10 cell culture plates. The following day, the cells were treated with compounds at concentrations of 100 and $200 \mu \mathrm{M}$ and with $1 \mu \mathrm{M}$ of 5-Azadc. The treatment was repeated for six days, every second day. On day six, cells were harvested. 
DNA extraction and luminometric methylation assay. DNA was extracted by phenol-chloroform as follows: cells were resuspended and incubated in DNA extraction buffer $(500 \mu \mathrm{L})$ containing proteinase $\mathrm{K}\left(20 \mu \mathrm{L} ; 20 \mathrm{mg} \mathrm{ml}^{-1}\right.$; Roche, Basel, Switzerland) at $50{ }^{\circ} \mathrm{C}$ for $12 \mathrm{~h}$. Samples were treated with RNAase A (50 $\mathrm{U} \mathrm{mg}^{-1}$; $30 \mathrm{~min}$; Roche) and phenol-chloroform (1:1). To precipitate DNA, ethanol [95\% (v/v)] was added. The pellet was washed in ethanol $70 \%$ and redissolved in DNAse free water. DNA was then digested with methylation sensitive (HpaII) or insensitive (MspI) restriction enzymes in combination with an internal control restriction enzyme (EcoRI) to normalize for the DNA input. Both HpaII and MspI restriction enzymes recognize and cleave 5 -CCGG-3' sequences producing $5^{\prime}$-CG overhangs, whereas EcoRI recognizes and cleaves $5^{\prime}$-GAATTC- $3^{\prime}$ sequences and produces $5^{\prime}$-AATT overhangs. The extent of cleavage is determined by a bioluminometric polymerase extension assay based on a four-step pyrosequencing reaction. Samples were incubated $\left(37^{\circ} \mathrm{C}, 4 \mathrm{~h}\right)$ and then heat inactivated $\left(80^{\circ} \mathrm{C}, 20 \mathrm{~min}\right)$. Digested genomic DNA $(15 \mu \mathrm{L})$ was mixed with pyrosequencing annealing buffer $(15 \mu \mathrm{L}$; Qiagen, Toronto, ON, Canada). Samples were transferred to 24-well pyrosequencing plates for sequencing (PyroMark 24; Biotage, Uppsala, Sweden). The nucleotide dispensation order used was based on the study by Pilsner et $a .^{48}$ Peak heights for $\mathrm{C}$ and A represent the HpaII and MspI cuts (methylation) and EcoRI (input DNA), respectively. The formula for calculating \% genomic methylation is: 1-[(HpaII (C)/EcoRI (A)/MspI (C)/EcoRI $(\mathrm{A}))] \times 100$. All samples were run in triplicate.

\section{Acknowledgements}

This work was supported by Pharmaqam, the Natural Sciences and Engineering Research Council of Canada (NSERC), the Université du Québec à Montréal (UQAM), and a grant from the Canadian Institute of Health Research to MS. PBA was funded by Région Midi-Pyrenées (Equipe d'Excellence) et FEDER (CNRS-Région Midi-Pyrenées). We thank Constellation Pharmaceuticals for generously testing our compounds against EZH2 and DOT1L. AG would like to thank Dr Brian Albrecht, Dr Richard Cummings, and Pr. Steve Bourgault for useful discussion. IMA thanks UQAM for an undergraduate scholarship, DC thanks the Israel Cancer Research Fund for a post-doctoral fellowship.

\section{References}

1 (a) S. L. Berger, T. Kouzarides, R. Shiekhattar and A. Shilatifard, Genes Dev., 2009, 23, 781-783; (b) A. Bird, Nature, 2007, 447, 396-398; (c) R. Bonasio, S. Tu and D. Reinberg, Science, 2010, 330, 612-616.

2 T. Kouzarides, Cell, 2007, 128, 693-705.

3 G. Auclair and M. Weber, Biochimie, 2012, 94, 2202-2211.

4 R. Z. Jurkowska, T. P. Jurkowski and A. Jeltsh, ChemBioChem, 2011, 12, 206-222.

5 (a) M. G. Goll, F. Kirpekar, K. A. Maggert, J. A. Yoder, C. L. Hsieh, X. Zhang, K. G. Golic, S. E. Jacobsen and
T. H. Bestor, Science, 2006, 311, 395-398; (b) M. Schaefer and F. Lyko, Chromosoma, 2010, 119, 35-40.

6 M. Okano, D. W. Bell, D. A. Haber and E. Li, Cell, 1999, 99, 247-257.

7 G. D. Kim, J. Ni, N. Kelesoglu, R. J. Roberts and S. Pradhan, EMBO J., 2002, 21, 4183-4195.

8 B. Stefanska, J. Huang, B. Bhattacharyya, M. Suderman, M. Hallett, Z.-G. Han and M. Szyf, Cancer Res., 2011, 71, 5891-5903.

9 A. P. Feinberg and B. Vogelstein, Nature, 1983, 301, 89-92.

10 (a) J. G. Herman and S. B. Baylin, N. Engl. J. Med., 2003, 349, 2042-2054; (b) S. Sharma, T. K. Kelly and P. A. Jones, Cacinogenesis, 2010, 31, 27-36.

11 (a) S. Ramchandani, S. K. Bhattacharya, N. Cervoni and M. Szyf, Proc. Natl. Acad. Sci. U. S. A., 1999, 96, 6107-6112; (b) M. Szyf, Annu. Rev. Pharmacol. Toxicol., 2009, 49, 243-263. 12 M. Szyf, Trends Pharmacol. Sci., 1994, 15, 233-238.

13 C. Egger, G. Liang, A. Aparicio and P. A. Jones, Nature, 2004, 429, 457-463.

14 M. Szyf, J. Neurodev. Disord., 2011, 3, 238-249.

15 H. G. Linhart, H. Lin, Y. Yamada, E. Moran, E. Steine, S. Gokhale, G. Lo, E. Cantu, M. Ehrich, T. He, A. Meissner and R. Jaenisch, Genes Dev., 2007, 21, 3110-3122.

16 (a) M. G. Coll and T. H. Bestor, Annu. Rev. Biochem., 2005, 74, 481-514; (b) Z. M. Svedruzic, Curr. Med. Chem., 2008, 15, 92106; (c) J. P. Issa and H. M. Kantarjian, Clin. Cancer Res., 2009, 15, 3938-3946; (d) T. B. Miranda and P. A. Jones, J. Cell. Physiol., 2007, 213, 384-390.

17 Many other epigenetic enzymes are also currently being explored as potential target for the development of therapeutic agents: (a) P. Jones, Med. Chem. Commun., 2012, 3, 135-161; (b) R. A. Copeland, E. J. Olhava and M. P. Scott, Curr. Opin. Chem. Biol., 2010, 14, 505-510; (c) N. Carey, Med. Chem. Commun., 2012, 3, 162-166; (d) E.-M. Bissinger, R. Heinke, W. Sippl and M. Jung, Med. Chem. Commun., 2010, 1, 114-124.

18 (a) J. Fahy, A. Jeltsch and P. B. Arimondo, Expert Opin. Ther. Pat., 2012, 22, 1427-1442; (b) M. Szyf, Biochim. Biophys. Acta, 2010, 1799, 750-759; (c) C. Gros, J. Fahy, L. Halby, I. Dufau, A. Erdmann, J.-M. Gregoire, F. Ausseil, S. Vispé and P. B. Arimondo, Biochimie, 2012, 94, 2280-2296; (d) Y. Itoh, T. Suzuki and N. Miyata, Mol. Biosyst., 2013, 9, 873-896.

19 J. M. Foulks, K. Mark Parnell, R. N. Nix, S. Chau, K. Swierczek, M. Sauders, K. Wright, T. F. Hendrickson, K.-K. Ho, M. V. McCullar and S. B. Kanner, J. Biomol. Screening, 2012, 17, 2-17.

20 (a) P. A. Jones and S. M. Taylor, Cell, 1980, 20, 85-93; (b) J. S. Garcia, N. Jain and L. A. Godley, OncoTargets Ther., 2010, 3, 1-13; (c) P. Fenaux, G. J. Mufti, E. HellstromLindberg, V. Santini, C. Finelli, A. Giagounidis, R. Schoch, N. Gattermann, G. Sanz, A. List, S. D. Gore, J. F. Seymour, J. M. Bennett, J. Byrd, J. Backstrom, L. Zimmerman, D. McKenzie, C. L. Beach and L. R. Silverman, Lancet Oncol., 2009, 10, 223-232; (d) D. P. Steensma, M. R. Baer, J. L. Slack, R. Buckstein, L. A. Godley, G. Garcia-Manero, M. Albitar, J. S. Larsen, S. Arora, M. T. Cullen and H. Kantarjian, J. Clin. Oncol., 2009, 27, 3842-3848. 
21 D. V. Santi, A. Norment and C. E. Garrett, Proc. Natl. Acad. Sci. U. S. A., 1984, 81, 6993-6997.

22 (a) N. Martinet, B. Y. Michel, P. Bertrand and R. Benhida, Med. Chem. Commun., 2012, 3, 263-273; (b) T. Suzuki, R. Tanaka, S. Hamada, H. Nakagawa and N. Miyata, Bioorg. Med. Chem. Lett., 2010, 20, 1124-1127; (c) Y.-S. Lin, A. Y. Shaw, S.-G. Wang, C.-C. Hsu, I.-W. Teng, M.-J. Tseng, T. H. M. Huang, C.-S. Chen, Y.-W. Leu and S.-H. Hsiao, J. Biomed. Sci., 2011, 18, 3; (d) S. Castellano, D. Kuck, M. Viviano, J. Yoo, F. López-Vallejo, P. Conti, L. Tamborini, A. Pinto, J. L. Medina-Franco and G. Sbardella, J. Med. Chem., 2011, 54, 7663-7677.

23 M. Z. Fang, Y. Wang, N. Ai, Z. Hou, Y. Sun, H. Lu, W. Welsh and C. S. Yang, Cancer Res., 2003, 63, 7563-7570.

24 Z. Liu, Z. Xie, W. Jones, R. E. Pavlovicz, S. Liu, J. Yu, P.-k. Li, J. Lin, J. R. Fuchs, G. Marcucci, C. Li and K. K. Chan, Bioorg. Med. Chem. Lett., 2009, 19, 706-709.

25 W. J. Lee and B. T. Zhu, Carcinogenesis, 2006, 27, 269277.

26 S. Majid, A. A. Dar, A. E. Ahmad, H. Hirata, K. Kawakami, V. Shahryari, S. Saini, Y. Tanaka, A. V. Dahiya, G. Khatri and R. Dahiya, Carcinogenesis, 2009, 30, 662-670.

27 B. Segura-Pacheco, C. Trejo-Becerril, E. Perez-Cardenas, L. Taja-Chayeb, I. Mariscal, A. Chavez, C. Acuna, A. M. Salazar, M. Lizano and A. Duenas-Gonzalez, Clin. Cancer Res., 2003, 9, 1596-1603.

28 (a) A. Villar-Garea, M. F. Fraga, J. Espada and M. Esteller, Cancer Res., 2003, 63, 4984-4989; (b) S. Castellano, D. Kuck, M. Sala, E. Novellino, F. Lyko and G. Sbardella, J. Med. Chem., 2008, 51, 2321-2325.

29 (a) B. H. Lee, S. Yegnasubramanian, X. H. Lin and W. G. Nelson, J. Biol. Chem., 2005, 280, 40749-40756; (b) L. Halby, C. Champion, C. Sénamaud-Beaufort, S. Ajjan, T. Drujon, A. Rajavelu, A. Ceccaldi, R. Jurkowska, O. Lequin, W. G. Nelson, A. Guy, A. Jeltsch, D. Guianvarc'h, C. Ferroud and P. B. Arimondo, ChemBioChem, 2012, 13, 157-165.

30 For an excellent review on natural products as modulators of epigenetic processes, see: F. L. Cherblanc, R. W. M. Davidson, P. Di Fruscia, N. Srimongkolpithak and M. J. Fuchter, Nat. Prod. Rep., 2013, 30, 605-624.

31 (a) J. L. Medina-Franco and J. Yoo, Mol. Diversity, 2013, 17, 337-344; (b) J. Yoo and J. L. Medina-Franco, Curr. Med. Chem., 2012, 19, 3475-3487.

32 A. Ceccaldi, A. Rajavelu, S. Ragozin, C. Sénamaud-Beaufort, P. Bashtrykov, N. Testa, H. Dali-Ali, C. Maulay-Bailly, S. Amand, D. Guianvarc'h, A. Jeltsch and P. Arimondo, ACS Chem. Biol., 2013, 8, 543-548.
33 (a) B. Brueckner, R. Garcia Boy, P. Siedlecki, T. Musch, H. C. Kliem, P. Zielenkiewicz, S. Suhai, M. Wiessler and F. Lyko, Cancer Res., 2005, 65, 6305-6311; (b) P. Siedlecki, R. Garcia Boy, T. Musch, B. Brueckner, S. Suhai, F. Lyko and P. Zielenkiewicz, J. Med. Chem., 2006, 49, 678-683.

34 J. Datta, K. Ghoshal, W. A. Denny, S. A. Gamage, D. G. Brooke, P. Phiasivongsa, S. Redkar and S. T. Jacob, Cancer Res., 2009, 69, 4277-4285.

35 D. Kuck, N. Singh, F. Lyko and J. L. Medina-Franco, Bioorg. Med. Chem., 2010, 18, 822-829.

36 A. Ceccaldi, A. Rajavelu, C. Champion, C. Rampon, R. Jurkowska, G. Jankevicius, C. Sénamaud-Beaufort, L. Ponger, N. Gagey, H. D. Ali, J. Tost, S. Vriz, S. Ros, D. Dauzonne, A. Jeltsch, D. Guianvarc'h and P. Arimondo, ChemBioChem, 2011, 12, 1337-1345.

37 R. Margueron and D. Reinberg, Nature, 2011, 469, 343-349. 38 E. Viré, C. Brenner, R. Deplus, L. Blanchon, M. Fraga, C. Didelot, L. Morey, A. Van Eynde, D. Bernard, J.-M. Vanderwinden, M. Bollen, M. Esteller, L. Di Croce, Y. de Launoit and F. Fuks, Nature, 2006, 439, 871-874.

39 (a) Q. Feng, H. Wang, H. H. Ng, H. Erdjument-Bromage, P. Tempst, K. Struhl and Y. Zhang, Curr. Biol., 2002, 12, 1052-1058; (b) J. Min, Q. Feng, Z. Li, Y. Zhang and R. M. Xu, Cell, 2003, 112, 711-723.

40 E. Therrien, P. Englebienne, A. G. Arrowsmith, R. MendozaSanchez, C. R. Corbeil, N. Weill, V. Campagna-Slater and N. Moitessier, J. Chem. Inf. Model., 2012, 52, 210-224.

41 J. D. Knox, F. D. Araujo, P. Bigey, A. D. Slack, G. B. Price, M. Zannis-Hadjopoulos and M. Szyf, J. Biol. Chem., 2000, 275, 17986-17990.

42 (a) M. R. Hassler and G. Egger, Biochimie, 2012, 94, 22192230; (b) C. Seidel, C. Florean, M. Schnekenburger, M. Dicato and M. Diederich, Biochimie, 2012, 94, 2264-2279. 43 (a) A. Mai and L. Altucci, Int. J. Biochem. Cell Biol., 2009, 41, 199-213; (b) Y. Boumber and J. P. Issa, Oncology, 2011, 25, 220-226.

44 S. Kummar, H. X. Chen, J. Wright, S. Holbeck, M. D. Millin, J. Tomaszewski, J. Zweibel, J. Collins and J. H. Doroshow, Nat. Rev. Drug Discovery, 2010, 9, 843-856.

45 G. R. Brown and A. J. Foubister, J. Med. Chem., 1984, 27, 7981.

46 D. Jia, R. Z. Jurkowska, X. Zhang, A. Jeltsch and X. Cheng, Nature, 2007, 449, 248-251.

47 (a) J. Min, Q. Feng, Z. Li, Y. Zhang and R. M. Xu, Cell, 2003, 112, 711-723; (b) R. K. McGinty, J. Kim, C. Chatterjee, R. G. Roeder and T. W. Muir, Nature, 2008, 453, 812-816.

48 J. R. Pilsner, A. L. Lazarus, D. H. Nam, R. J. Letcher, C. Sonne, R. Dietz and N. Basu, Mol. Ecol., 2010, 19, 307-314. 